Supplement of

\title{
Source apportionment of carbonaceous aerosols in Beijing with radiocarbon and organic tracers: insight into the differences between urban and rural sites
}

Siqi Hou et al.

Correspondence to: Roy M. Harrison (r.m.harrison@bham.ac.uk) and Zongbo Shi (z.shi@bham.ac.uk)

The copyright of individual parts of the supplement might differ from the article licence. 
8 During the wintertime, air masses transported to Beijing were mainly from Inner Mongolia, Shanxi

9 and Hebei, where the open burning activities were associated with maize straw (Zhang et al., 2019).

10 During summer, air masses from Shandong, Hebei, Liaoning and Tianjin may bring particles from

11 burning of wheat straw. However, for Inner Mongolia and Shanxi, little wheat is grown in these areas

12 (Zhang et al., 2019; Zhou et al., 2017) and the influence of wheat straw burning is less important. The

13 fire spot intensity, transport direction and sources of biomass burning are summarized in Table S1.

14 The high fire spot intensity indicates a strong likelihood of regional transport. However, the 15 concentrations of LG would decrease with atmospheric transport by aging, varying with 16 environmental conditions (Bhattarai et al., 2019), which can be used to infer the influence from regional transport and local emissions. For example, with similar $\mathrm{PM}_{2.5}$ concentrations, the LG concentration on 26 November was much lower than that on 3 December. Considering the different

19 intensity of fire spots between the two days, LG on 26 November may arise more from regional 20 transport instead of local emissions. Moreover, the LG concentration on 2 December was similar to 21 that on 3 December, but the $\mathrm{PM}_{2.5}$ concentration was much lower. This implies a contribution from local sources in addition to regional transport on 2 December.

As mentioned in the main text, softwood, maize straw and wheat straw are the main types of biomass fuels used within the region. The ratios of EC/OC and OC/LG from softwood, maize straw and wheat straw are summarized in Table S2.

As the fraction of LG from wood burning $\left(f_{\text {wood }}\right)$ and straw burning $\left(f_{\text {straw }}=1-f_{\text {wood }}\right)$ are each in the range of 0 to 1 , only those matching this limitation were selected when calculating $\mathrm{OC}_{\mathrm{bb}}$. Emission factors of LG from various biofuels showed that the LG emission from wheat straw was hundreds of times higher than from the values for wood combustion, while the emission factors are similar 
31 between maize and wood (Yan et al., 2018). It means that although the consumption of wheat straw may be less than that of wood, LG emission from wheat straw may exceed that from wood, and $\mathrm{f}_{\text {wood }}$ may be quite small in summer. Besides, the sum of calculated $\mathrm{OC}_{\text {straw }}$ and $\mathrm{OC}_{\mathrm{wood}}$ should not exceed the measured $\mathrm{OC}_{\mathrm{nf}}$ concentrations, which is another limitation for selecting EC/OC and OC/LG ratios. Hence, ratios of softwood from No. 25 to No. 37 in Table S3 with ratios of maize (No. 48 in Table S3) were used for the wintertime, and No. 30-37 with No. 42-45, 50 from softwood and wheat straw respectively were used in the summertime estimation of $\mathrm{f}_{\text {wood }}$

$\mathrm{OC}_{\mathrm{bb}}$ from each type of softwood and crop straw combination can be estimated once $\mathrm{f}_{\text {wood }}$ was confirmed, and then these were averaged. To further assess the sensitivity of the calculated $\mathrm{OC}_{\mathrm{bb}}$ results to the different ratio sets, concentrations of $\mathrm{OC}_{\mathrm{bb}}$ for each set of ratios have been plotted vs. the averaged values (Fig. S4). Compared to $\mathrm{OC}_{\text {wood, }}$ concentrations of $\mathrm{OC}_{\text {straw }}$ show a small spread, and are in narrow ranges. It means the $\mathrm{OC}_{\text {straw }}$ are less affected by the varying ratios, as the range of ratios is smaller. According to Fig. S4, there are large uncertainties attached to the estimated values of $\mathrm{OC}_{\mathrm{wood}}$, but not $\mathrm{OC}_{\text {straw. }}$. The uncertainties from $\mathrm{OC}_{\mathrm{bb}}$ can further affect the estimation of $\mathrm{OC}$ from cooking, but have no influence on estimates of SOC, which are determined from the $(\mathrm{OC} / \mathrm{EC})_{\min }$ ratios. The accuracy of this extended Gelencsér method would increase if the softwood types and ratios were confirmed.

The concentrations and contributions of $\mathrm{OC}_{\mathrm{bb}}$ are shown in Fig. S5. The uncertainties of $\mathrm{OC}_{\mathrm{bb}}$ are calculated considering the uncertainties of $\mathrm{EC}_{\mathrm{nf}}$ and $\mathrm{LG}$ :

$$
\mathrm{u}\left(\mathrm{OC}_{\mathrm{bb}}\right)=\sqrt{\sum\left[\left(\frac{\mathrm{a}-\mathrm{b}}{\mathrm{ac}-\mathrm{bd}}\right)^{2} \mathrm{u}\left(\mathrm{EC}_{\mathrm{nf}}\right)^{2}+\left(\frac{\mathrm{abc}-\mathrm{abd}}{\mathrm{ac}-\mathrm{bd}}\right)^{2} \mathrm{u}(\mathrm{LG})^{2}\right]}
$$


The average uncertainty of the LG concentration is $15 \%$. The uncertainty of $\mathrm{EC}_{\mathrm{nf}}$ is calculated by

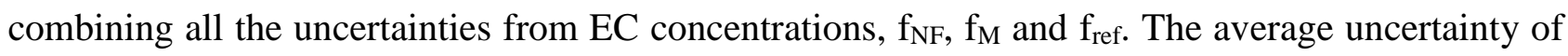
$\mathrm{OC}_{\mathrm{bb}}$ is $48.6 \%$.

\section{Determination of $(\mathrm{OC} / \mathrm{EC})_{\mathrm{f}}$, min and $(\mathrm{OC} / \mathrm{EC})_{\mathrm{nf}}$, min ratios and the estimation of $\mathrm{POC}_{\mathrm{f}}$ and $\mathrm{POC}_{\mathrm{nf}}$}

OC/EC ratios are seen as an indicator of aerosol emission sources to estimate the POC and SOC concentrations. ${ }^{14} \mathrm{C}$ analysis can provide $\mathrm{OC}$ to $\mathrm{EC}$ ratios from fossil and non-fossil sources $\left((\mathrm{OC} / \mathrm{EC})_{\mathrm{f}}\right.$ and $\left.(\mathrm{OC} / \mathrm{EC})_{\mathrm{nf}}\right)$. Herein, we use the lowest $(\mathrm{OC} / \mathrm{EC})_{\mathrm{f}}$ and $(\mathrm{OC} / \mathrm{EC})_{\mathrm{nf}}$ ratios $\left((\mathrm{OC} / \mathrm{EC})_{\mathrm{f}}\right.$, min and $(\mathrm{OC} / \mathrm{EC})_{\mathrm{nf}, \mathrm{min}}$, respectively) to represent primary OC/EC emission ratio to calculate primary fossilderived and non-fossil-derived $\mathrm{OC}\left(\mathrm{POC}_{\mathrm{f}}\right.$ and $\left.\mathrm{POC}_{\mathrm{nf}}\right)$ respectively. To avoid the overestimation of $\mathrm{POC}_{\mathrm{f}}$ and $\mathrm{POC}_{\mathrm{nf}}$ from the measured $(\mathrm{OC} / \mathrm{EC})_{\mathrm{f}}$, min and $(\mathrm{OC} / \mathrm{EC})_{\mathrm{nf}}$, min due to the limited samples for ${ }^{14} \mathrm{C}$ analysis in this study, it is necessary to evaluate $(\mathrm{OC} / \mathrm{EC})_{\mathrm{nf}}$, min and $(\mathrm{OC} / \mathrm{EC})_{\mathrm{f}}$, min ratios for the whole sampling period.

The relationship of $(\mathrm{OC} / \mathrm{EC})_{\mathrm{nf}}$ and $(\mathrm{OC} / \mathrm{EC})_{\mathrm{f}}$ with $\mathrm{OC} / \mathrm{EC}$ can be described as follow,

$5 \quad\left(\frac{\mathrm{OC}}{\mathrm{EC}}\right)_{\mathrm{nf}}=\frac{\mathrm{f}_{\mathrm{NF}, \mathrm{OC}}}{\mathrm{f}_{\mathrm{NF}, \mathrm{EC}}} \times \frac{\mathrm{OC}}{\mathrm{EC}}$

$\left(\frac{\mathrm{OC}}{\mathrm{EC}}\right)_{\mathrm{f}}=\left(\frac{1-\mathrm{f}_{\mathrm{NF}, \mathrm{OC}}}{1-\mathrm{f}_{\mathrm{NF}, \mathrm{EC}}}\right) \times \frac{\mathrm{OC}}{\mathrm{EC}}$

7 where $f_{N F, O C}$ and $f_{N F, E C}$ are the non-fossil fractions of OC and EC, $\left(1-f_{N F, ~ O C}\right)$ and $\left(1-f_{N F, E C}\right)$ are the fossil fractions of OC and EC.

Ratios of $(\mathrm{OC} / \mathrm{EC})_{\mathrm{nf}}$ are determined by $\frac{\mathrm{f}_{\mathrm{NF}, \mathrm{OC}}}{\mathrm{f}_{\mathrm{NF}, \mathrm{EC}}}$ and $\mathrm{OC} / \mathrm{EC}$, therefore $(\mathrm{OC} / \mathrm{EC})_{\mathrm{nf}}$, min can be roughly quantified by multiplying the lowest $5 \%$ OC/EC ratios with the lowest two $\frac{f_{\mathrm{NF}, \mathrm{OC}}}{\mathrm{f}_{\mathrm{NF}, \mathrm{EC}}}$ ratios. Similarly, $(\mathrm{OC} / \mathrm{EC})_{\mathrm{f}}$, min can be estimated by multiplying the lowest $5 \% \mathrm{OC} / \mathrm{EC}$ ratios with the lowest two $2\left(\frac{1-\mathrm{f}_{\mathrm{NF}, \mathrm{OC}}}{1-\mathrm{f}_{\mathrm{NF}, \mathrm{EC}}}\right)$ ratios. The estimated $(\mathrm{OC} / \mathrm{EC})_{\mathrm{nf}}$, min and $(\mathrm{OC} / \mathrm{EC})_{\mathrm{f}, \text { min }}$ ratios for IAP and PG sites in winter 
and summer sampling period were listed in Table $\mathrm{S} 4$. The estimated $(\mathrm{OC} / \mathrm{EC})_{\mathrm{nf}}$, min and $(\mathrm{OC} / \mathrm{EC})_{\mathrm{f}, \min }$ ratios are within the values of OC/EC emission ratios from coal combustion (1.5-15), traffic emission (0.69-1.01), and biomass burning (3-7) ( $\mathrm{Ni}$ et al., 2018). Higher (OC/EC)f, min ratios in winter are consistent with the fact of elevated coal combustion compared to traffic emissions. It indicated the evaluation of $(\mathrm{OC} / \mathrm{EC})_{\mathrm{nf}}$, min and $(\mathrm{OC} / \mathrm{EC})_{\mathrm{f}, \min }$ ratios are reasonable.

\section{Discussion of OC from cooking and OC from other potential non-fossil sources.}

Cholesterol is an organic marker which is used to calculate OC from cooking in previous study. Thus, calculations of $\mathrm{OC}_{\mathrm{ck}-\mathrm{ch}}$ by cholesterol concentrations multiplying $\mathrm{OC}$ to cholesterol ratios (Zhao et al., 2015; Wu et al., 2021) were conducted to compare the EG method result ( $\left.\mathrm{OC}_{\mathrm{ck}-\mathrm{EG}}\right)$. The concentrations of cholesterol in 25 selected samples with the corresponding $\mathrm{OC}$ from cooking $\left(\mathrm{OC}_{\mathrm{ck}-}\right.$ ch) are summarized in Table S5. The methodology of cholesterol determination is described in Xu et. al (2020). The average concentrations of $\mathrm{OC}_{\mathrm{ck}-\mathrm{ch}}$ are $2.08 \pm 1.16 \mu \mathrm{g} \mathrm{m}^{-3}$ and $1.64 \pm 1.01 \mu \mathrm{g} \mathrm{m}^{-3}$ at IAP in winter and summer, $2.65 \pm 1.06 \mu \mathrm{g} \mathrm{m}^{-3}$ and $0.92 \pm 0.43 \mu \mathrm{g} \mathrm{m}^{-3}$ at PG in winter and summer. The $\mathrm{OC}_{\mathrm{ck}-\mathrm{ch}}$ concentrations are 1.8 times higher than the $\mathrm{OC}_{\mathrm{ck}}$ from the $\mathrm{EG}$ method $\left(\mathrm{OC}_{\mathrm{ck}-\mathrm{EG}}\right)$ on average at IAP, and will result in the values of $\mathrm{OC}_{\mathrm{bb}}+\mathrm{OC}_{\mathrm{ck}-\mathrm{ch}}$ being much higher than $\mathrm{POC}_{\mathrm{nf}}$. It is suggested that the $\mathrm{OC}_{\mathrm{ck}-\mathrm{ch}}$ may contain some secondary $\mathrm{OC}$. At PG, however, concentrations of $\mathrm{OC}_{\mathrm{ck}-\mathrm{ch}}$ are only half of $\mathrm{OC}_{\mathrm{ck}-\mathrm{EG}}$. the $\mathrm{OC}_{\mathrm{ck}-\mathrm{EG}}$ is calculated by subtracting $\mathrm{OC}_{\mathrm{bb}}$ from $\mathrm{POC}_{\mathrm{nf}}$ assuming it arises mainly from cooking. Here, the much higher $\mathrm{OC}_{\mathrm{ck}-\mathrm{EG}}$ than $\mathrm{OC}_{\mathrm{ck}-\mathrm{ch}}$ at $\mathrm{PG}$ suggest that the $\mathrm{OC}_{\mathrm{ck}-\mathrm{Eg}}$ may include other primary sources.

Comparisons of $\mathrm{OC}_{\mathrm{ck}-\mathrm{ch}}$ with $\mathrm{OC}_{\mathrm{ck}-\mathrm{EG}}, \mathrm{OC}_{\mathrm{ck}}$ from the $\mathrm{CMB}$ model and cooking $\mathrm{OC}$ from AMS/ACSM-PMF are shown in Figure 1(Figure S8 in SI). The concentrations of $\mathrm{OC}_{\mathrm{ck} \text {-ch }}$ are not well

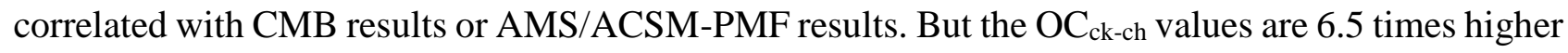
than CMB results on average, and 0.91 times the AMS/ACSM-PMF results. It is possible that the $\mathrm{OC}_{\mathrm{ck}-\mathrm{ch}}$ may contain secondary OC. 
$\mathrm{OC}_{\mathrm{ck}-\mathrm{ch}}$ at $\mathrm{PG}$ is half of $\mathrm{OC}_{\mathrm{ck}-\mathrm{EG}}$. We found the differences between $\mathrm{OC}_{\mathrm{ck}-\mathrm{EG}}$ and $\mathrm{OC}_{\mathrm{ck}-\mathrm{ch}}\left(\mathrm{OC}_{\mathrm{onf}}\right)$ at $\mathrm{PG}$ are positively correlated with crustal elements, $\mathrm{Si}, \mathrm{Al}, \mathrm{Fe}$ and $\mathrm{Ti}$ (shown in Figure 2, Figure S9 in SI).

99 This indicates that the $\mathrm{OC}_{\mathrm{ck}-\mathrm{EG}}$ may include $\mathrm{OC}$ fractions from primary sources like dust. The filters 100 collected during the APHH-campaign have been subject to elemental analysis with XRF and ICP101 MS. The detailed methods of elemental analysis can be found in Srivastava et al (2020).

102 103 104

105

106 107 108 109

Enrichment factors (EFs) can be used to study the degree of elemental enrichment in ambient particles and can also help to determine whether they are from natural or anthropogenic emissions. The calculation of EFs are as follow,

$$
\mathrm{EF}=\frac{\left({ }_{\mathrm{x}} / \mathrm{C}_{\mathrm{Al}}\right)_{\mathrm{PM}_{2.5}}}{\left(\mathrm{C}_{\mathrm{x}} / \mathrm{C}_{\mathrm{Al}}\right)_{\text {Soil }}}
$$

Where, $\left(\mathrm{C}_{\mathrm{x}} / \mathrm{C}_{\mathrm{Al}}\right)_{\mathrm{PM}_{2.5}}$ is the concentration ratio of $\mathrm{x}$ to $\mathrm{Al}$ in the measured $\mathrm{PM}_{2.5}$ samples, $\left(\mathrm{C}_{\mathrm{x}} / \mathrm{C}_{\mathrm{Al}}\right)_{\text {Soil }}$ is the concentration ratio of $\mathrm{x}$ to $\mathrm{Al}$ of fugitive dust in Chinese Loess Plateau (Cao et al., 2008), respectively. Here, $\mathrm{Al}$ is the reference element due to its stability and immunity to human interference (Uematsu et al., 1983; Zhang et al., 2003).

The EFs of $\mathrm{Si}, \mathrm{Fe}$ and $\mathrm{Ti}$ are listed in Table 1 (shown as Table $\mathrm{S} 5 \mathrm{in} \mathrm{SI}$ ). $\mathrm{EF}(\mathrm{Si}$ ) is in the range of 0.41 to 1.07 , indicating that $\mathrm{Si}$ is mostly from natural sources. $\mathrm{EF}(\mathrm{Fe})$ and $\mathrm{EF}(\mathrm{Ti})$ are in range of 0.02 10.82 and 0-6.38, respectively, indicating that $\mathrm{Fe}$ and $\mathrm{Ti}$ are from mixed sources. Thus, we used $\mathrm{Si}$ concentrations and the Si to OC ratio from the Chinese Loess Plateau (Cao et al., 2008) and from Beijing road dust samples (Hu et al., 2019) to calculate a possible range $\mathrm{OC}$ from dust $\left(\mathrm{OC}_{\mathrm{dt}}\right)$. We also calculate $\mathrm{OC}$ from dust $\left(\mathrm{OC}_{\mathrm{dt}-\mathrm{Al}}\right)$ using $\mathrm{Al}$ concentrations and the $\mathrm{Al}$ to $\mathrm{OC}$ ratio for comparison. The ranges of $\mathrm{OC}_{\mathrm{dt}}$ and $\mathrm{OC}_{\mathrm{dt}-\mathrm{Al}}$ are listed in Table 1 . The $\mathrm{OC}_{\mathrm{dt}}$ and $\mathrm{OC}_{\mathrm{dt}-\mathrm{Al}}$ would result in a contribution to OC of $0.1-22.8 \%$ and $0.2-22.1 \%$, respectively. And the calculated $\mathrm{OC}_{\mathrm{dt}}$ would contribute $1.9 \%$ to $192.5 \%$ of $\mathrm{OC}_{\mathrm{onf}}$ for PG site. It implies the $\mathrm{OC}$ from dust may be a major contributor to the primary non-fossil sources at PG. 
120 Our other research on source apportionment of $\mathrm{PM}_{2.5}$ using PMF has presented a detailed study of 121 dust contributions (Srivastava et al., 2020). It showed that the crustal dust made a significant 122 contribution to OC and EC. But it cannot clearly be attributed to soil dust or road dust, and contains 123 mixed characteristics. The estimated dust contributions in urban Beijing were $12.7 \%$ during haze 124 periods $\left(\mathrm{PM}_{2.5}>75 \mu \mathrm{g} \mathrm{m}^{-3}\right)$ and $35.2 \%$ during non-haze periods $\left(\mathrm{PM}_{2.5}<75 \mu \mathrm{g} \mathrm{m}^{-3}\right)$. The huge 125 discrepancy between the methods is not easily explained, but Srivastava et al. (2020) urge caution in 126 accepting their results. 
128 Bhattarai, H., Saikawa, E., Wan, X., Zhu, H., Ram, K., Gao, S., Kang, S., Zhang, Q., Zhang, Y., Wu, 129 G., Wang, X., Kawamura, K., Fu, P., and Cong, Z.: Levoglucosan as a tracer of biomass burning: 130 Recent progress and perspectives, Atmos. Res., 220, https://doi.org/10.1016/j.atmosres.2019.01.004 $13120-33,2019$.

132 Cao, J. J., Chow, J. C., Watson, J. G., Wu, F., Han, Y. M., Jin, Z. D., Shen, Z. X., and An, Z. S.: Size133 differentiated source profiles for fugitive dust in the Chinese Loess Plateau, Atmos. Environ., 42, 134 2261-2275, https://doi.org/10.1016/i.atmosenv.2007.12.041, 2008.

Dhammapala, R., Claiborn, C., Jimenez, J., Corkill, J., Gullett, B., Simpson, C., and Paulsen, M.: Emission factors of PAHs, methoxyphenols, levoglucosan, elemental carbon and organic carbon from simulated wheat and Kentucky bluegrass stubble burns, Atmos. Environ., 41, 2660-2669, https://doi.org/10.1016/j.atmosenv.2006.11.023, 2007.

Fine, P. M., Cass, G. R., and Simoneit, B. R. T.: Chemical characterization of fine particle emissions from fireplace combustion of woods grown in the northeastern United States, Environ. Sci. Technol., 35, 2665-2675, https://doi.org/10.1021/es001466k, 2001.

Fine, P. M., Cass, G. R. and Simoneit, B. R. T.: Chemical characterization of fine particle emissions from the fireplace combustion of woods grown in the southern United States, Environ. Sci. Technol., 36, 1442-1451, https://doi.org/10.1021/es0108988, 2002.

Fine, P. M., Cass, G. R., and Simoneit, B. R. T.: Chemical characterization of fine particle emissions from the wood stove combustion of prevalent United States tree species, Environ. Eng. Sci., 21, 705721, https://doi.org/10.1089/ees.2004.21.705, 2004.

Fushimi, A., Saitoh, K., Hayashi, K., Ono, K., Fujitani, Y., Villalobos, A. M., Shelton, B. R., Takami, A., Tanabe, K. \& Schauer, J. J.: Chemical characterization and oxidative potential of particles emitted from open burning of cereal straws and rice husk under flaming and smoldering conditions, Atmos. Environ., 163, 118-127, https://doi.org/10.1016/j.atmosenv.2017.05.037, 2017.

Gonçalves, C., Alves, C., Evtyugina, M., Mirante, F., Pio, C., Caseiro, A., Schmidl, C., Bauer, H., 153 and Carvalho, F.: Characterisation of $\mathrm{PM}_{10}$ emissions from woodstove combustion of common woods grown in Portugal, Atmos. https://doi.org/10.1016/j.atmosenv.2010.07.026, 2010. https://doi.org/10.1021/es0111683, 2002. 
Hays, M. D., Fine, P. M., Geron, C. D., Kleeman, M. J., and Gullett, B. K.: Open burning of agricultural biomass: Physical and chemical properties of particle-phase emissions, Atmos. Environ., 39, 6747-6764, https://doi.org/10.1016/j.atmosenv.2005.07.072, 2005.

Hu, Y., Li, M., Yan, X., Zhang, C.: Characteristics and Interannual Variation of Chemical Components in Typical Road Dust in Beijing. Environmental Science, 40, 1645-1655, https://doi.org/10.13227/j.hjkx.201808224, 2019.

Liu, J., Li, J., Zhang, Y., Liu, D., Ding, P., Shen, C., Shen, K., He, Q., Ding, X., Wang, X., Chen, D., Szidat, S., and Zhang, G.: Source Apportionment Using Radiocarbon and Organic Tracers for PM2.5 Carbonaceous Aerosols in Guangzhou, South China: Contrasting Local- and Regional-Scale Haze Events, Environ. Sci. Technol., 48, 12002-12011, 10.1021/es503102w, 2014.

Mazzoleni, L. R., Zielinska, B., and Moosmüller, H.: $\quad$ Emissions of levoglucosan, methoxy phenols, and organic acids from prescribed burns, laboratory combustion of wildland fuels, and residential wood combustion, Environ. Sci. Technol., 41, 2115-2122, https://doi.org/10.1021/es061702c, 2007.

Ni, H. Y., Huang, R.-J., Cao, J. J., Liu, W. G., Zhang, T., Wang, M., Meijer, H. A. J., and Dusek, U.: Source apportionment of carbonaceous aerosols in Xi'an, China: insights from a full year of measurements of radiocarbon and the stable isotope ${ }^{13} \mathrm{C}$, Atmos. Chem. Phys., 18, 16,363-16,383, https://doi.org/10.5194/acp-18-16363-2018, 2018.

Ni, H. Y., Huang, R. J., Cao, J. J., Dai, W. T., Zhou, J. M., Deng, H. Y., Aerts-Bijma, A., Meijer, H. A. J., and Dusek, U.: High contributions of fossil sources to more volatile organic aerosol, Atmospheric Chemistry and Physics, 19, 10405-10422, 10.5194/acp-19-10405-2019, 2019.

Sang-Arlt, X., Fu, H. X., Zhang, Y. A., Ding, X., Wang, X. M., Zhou, Y. N., Zou, L. L., Zellmer, G. F., and Engling, G.: Carbonaceous aerosol emitted from biofuel household stove combustion in South China, Atmosphere, 11, 112, https://doi.org/10.3390/atmos11010112, 2020.

Schauer, J. J., Kleeman, M. J., Cass, G. R., and Simoneit, B. R. T.: $\quad$ Measurement of emissions from air pollution sources. 3. $\mathrm{C}_{1}-\mathrm{C}_{29}$ organic compounds from fireplace combustion of wood, Environ. Sci. Technol., 35, 1716-1728, https://doi.org/10.1021/es001331e, 2001.

Schmidl, C., Bauer, H., Dattler, A., Hitzenberger, R., Weissenboeck, G., Marr, I. L., and Puxbaum, H.: Chemical characterisation of particle emissions from burning leaves, Atmos. Environ., 42, 9070-9079, https://doi.org/10.1016/j.atmosenv.2008.09.010, 2008a.

Schmidl, C., Marr, L. L., Caseiro, A., Kotianová, P., Berner, A., Bauer, H., Kasper-Giebl, A., and Puxbaum, H.: Chemical characterisation of fine particle emissions from wood stove combustion of common woods growing in mid-European Alpine regions, Atmos. Environ., 42, 126-141, https://doi.org/10.1016/j.atmosenv.2007.09.028, 2008b. 
Srivastava, D., Xu, J., Vu, T. V., Liu, D., Li, L., Fu, P., Hou, S., Shi, Z., Harrison, R. M.: Insight into PM2.5 sources by applying Positive Matrix factorization (PMF) at an urban and rural site of Beijing, (in review), 2020.

Sun, J., Shen, Z. X., Zhang, Y., Zhang, Q., Lei, Y. L., Huang, Y., Niu, X. Y., Xu, H. M., Cao, J. J., Ho, S. S. H., and Li, X. X.: Characterization of $\mathrm{PM}_{2.5}$ source profiles from typical biomass burning of maize straw, wheat straw, wood branch, and their processed products (briquette and charcoal) in China, Atmos. Environ., 205, 36-45, https://doi.org/10.1016/j.atmosenv.2019.02.038, 2019.

Uematsu, M., Duce, R. A., Prospero, J. M., Chen, L., Merrill, J. T., and McDonald, R. L.: Transport of mineral aerosol from Asia Over the North Pacific Ocean, Journal of Geophysical Research: Oceans, 88, 5343-5352, https://doi.org/10.1029/JC088iC09p05343, 1983.

Xu, J., Srivastava, D., Wu, X., Hou, S., Vu, Tuan V., Liu, D., Sun, Y., Vlachou, A., Moschos, V., Salazar, G., Szidat, S., Prévôt, A. S. H., Fu, P., Harrison, R. M., and Shi, Z.: An evaluation of source apportionment of fine OC and PM2.5 by multiple methods: APHH-Beijing campaigns as a case study, Faraday Discussions, https://doi.org/10.1039/D0FD00095G, 2021.

Wang, Z., Bi, X., Sheng, G., and Fu, J.: Characterization of organic compounds and molecular tracers from biomass burning smoke in South China I: Broad-leaf trees and shrubs, Atmos. Environ., 43, 3096-3102, https://doi.org/10.1016/j.atmosenv.2009.03.012, 2009.

Yan, C., Zheng, M., Sullivan, A. P., Shen, G., Chen, Y., Wang, S., Zhao, B., Cai, S., Desyaterik, Y., Li, X., Zhou, T., Gustafsson, Ö., and Collett, Jr. J. L.: Residential coal combustion as a source of levoglucosan in China, Environ. Sci. Technol., 52, 1665-1674, https://doi.org/10.1021/acs.est.7b05858, 2018.

Zhang, X. Y., Gong, S. L., Shen, Z. X., Mei, F. M., Xi, X. X., Liu, L. C., Zhou, Z. J., Wang, D., Wang, Y. Q., and Cheng, Y.: Characterization of soil dust aerosol in China and its transport and distribution during 2001 ACE-Asia: 1. Network observations, Journal of Geophysical Research: Atmospheres, 108, https://doi.org/10.1029/2002JD002632, 2003.

Zhang, X., Lu, Y., Wang, Q. G., and Qian, X.: A high-resolution inventory of air pollutant emissions from crop residue burning in China, Atmos. Environ., 213, 207-214, https://doi.org/10.1016/j.atmosenv.2019.06.009, 2019.

Zhang, Y. L., Perron, N., Ciobanu, V. G., Zotter, P., Minguillón, M. C., Wacker, L., Prévôt, A. S. H., Baltensperger, U., and Szidat, S.: On the isolation of OC and EC and the optimal strategy of radiocarbon-based source apportionment of carbonaceous aerosols, Atmos. Chem. Phys, 12, 10,84110,856, https://doi.org/10.5194/acp-12-10841-2012, 2012. 
225 Zhang, Y.-X., Shao, M., Zhang, Y.-H., Zeng, L.-M., He, L.-Y., Zhu, B., Wei, Y.-J., and Zhu, X.-L.: 226 Source profiles of particulate organic matters emitted from cereal straw burnings, J. Environ. Sci., 227 19, 167-175, https://doi.org/10.1016/S1001-0742(07)60027-8, 2007.

228 Zhao, X. Y., Hu, Q. H., Wang, X. M., Ding, X., He, Q. F., Zhang, Z., Shen, R. Q., Lu, S. J., Liu, T. 229 Y., Fu, X. X., and Chen, L. G.: Composition profiles of organic aerosols from Chinese residential 230 cooking: case study in urban Guangzhou, south China, Journal of Atmospheric Chemistry, 72, 1-18, $231 \quad 10.1007 / \mathrm{s} 10874-015-9298-0,2015$.

232 Zhou, Y., Xing, X., Lang, J., Chen, D., Cheng, S., Wei, L., Wei, X., and Liu, C.: A comprehensive 233 biomass burning emission inventory with high spatial and temporal resolution in China, Atmos. 234 Chem. Phys., 17, 2839-2864, https://doi.org/10.5194/acp-17-2839-2017, 2017. 
235 Table S1. Pearson correlations of species at IAP and PG sites.

\begin{tabular}{|c|c|c|c|c|c|c|c|}
\hline IAP winter & $\mathrm{PM}_{2.5}$ & $\mathrm{OC}$ & $\mathrm{EC}$ & $\mathrm{K}^{+}$ & LG & $\mathrm{MN}$ & GA \\
\hline $\mathrm{PM}_{2.5}$ & 1.00 & & & & & & \\
\hline $\mathrm{OC}$ & 0.91 & 1.00 & & & & & \\
\hline $\mathrm{EC}$ & 0.86 & 0.92 & 1.00 & & & & \\
\hline $\mathrm{K}^{+}$ & 0.74 & 0.67 & 0.71 & 1.00 & & & \\
\hline LG & 0.56 & 0.60 & 0.74 & 0.51 & 1.00 & & \\
\hline $\mathrm{MN}$ & 0.52 & 0.57 & 0.72 & 0.48 & 0.99 & 1.00 & \\
\hline GA & 0.52 & 0.55 & 0.70 & 0.52 & 0.98 & 0.97 & 1.00 \\
\hline PG winter & $\mathrm{PM}_{2.5}$ & $\mathrm{OC}$ & EC & $\mathrm{K}^{+}$ & LG & $\mathrm{MN}$ & GA \\
\hline $\mathrm{PM}_{2.5}$ & 1.00 & & & & & & \\
\hline $\mathrm{OC}$ & 0.95 & 1.00 & & & & & \\
\hline $\mathrm{EC}$ & 0.85 & 0.93 & 1.00 & & & & \\
\hline $\mathrm{K}^{+}$ & 0.88 & 0.78 & 0.70 & 1.00 & & & \\
\hline LG & 0.89 & 0.89 & 0.81 & 0.86 & 1.00 & & \\
\hline MN & 0.85 & 0.85 & 0.82 & 0.84 & 0.94 & 1.00 & \\
\hline GA & 0.88 & 0.85 & 0.74 & 0.84 & 0.95 & 0.94 & 1.00 \\
\hline $\begin{array}{l}\text { IAP } \\
\text { summer }\end{array}$ & $\mathrm{PM}_{2.5}$ & OC & $\mathrm{EC}$ & $\mathrm{K}^{+}$ & LG & $\mathrm{MN}$ & GA \\
\hline $\mathrm{PM}_{2.5}$ & 1.00 & & & & & & \\
\hline $\mathrm{OC}$ & 0.72 & 1.00 & & & & & \\
\hline $\mathrm{EC}$ & 0.34 & 0.79 & 1.00 & & & & \\
\hline $\mathrm{K}+$ & 0.65 & 0.64 & 0.36 & 1.00 & & & \\
\hline LG & 0.52 & 0.59 & 0.36 & 0.85 & 1.00 & & \\
\hline $\mathrm{MN}$ & 0.47 & 0.55 & 0.37 & 0.80 & 0.97 & 1.00 & \\
\hline GA & 0.41 & 0.59 & 0.54 & 0.59 & 0.79 & 0.85 & 1.00 \\
\hline $\begin{array}{l}\text { PG } \\
\text { summer }\end{array}$ & $\mathrm{PM}_{2.5}$ & OC & $\mathrm{EC}$ & $\mathrm{K}^{+}$ & LG & $\mathrm{MN}$ & GA \\
\hline $\mathrm{PM}_{2.5}$ & 1.00 & & & & & & \\
\hline $\mathrm{OC}$ & 0.60 & 1.00 & & & & & \\
\hline $\mathrm{EC}$ & 0.41 & 0.75 & 1.00 & & & & \\
\hline $\mathrm{K}+$ & 0.65 & 0.80 & 0.57 & 1.00 & & & \\
\hline LG & 0.42 & 0.46 & 0.32 & 0.51 & 1.00 & & \\
\hline $\mathrm{MN}$ & 0.47 & 0.22 & -0.03 & 0.17 & 0.65 & 1.00 & \\
\hline GA & 0.53 & 0.30 & 0.03 & 0.22 & 0.33 & 0.55 & 1.00 \\
\hline
\end{tabular}

236 LG, MN and GA referred to levoglucosan, mannosan and galactosan, respectively. 
238 Table S2. Summary of fire spot intensity, transport direction and sources of biomass burning.

\begin{tabular}{|c|c|c|c|c|c|c|c|}
\hline Site & Date & $\begin{array}{l}\mathrm{PM}_{2.5} \\
\mu \mathrm{g} \mathrm{m}^{-3}\end{array}$ & $\begin{array}{l}\mathrm{EC}_{\mathrm{nf}} \\
\mu \mathrm{g} \mathrm{m}^{-3}\end{array}$ & $\begin{array}{l}\mathrm{LG} \\
\mathrm{ng} \mathrm{m}^{-3}\end{array}$ & $\begin{array}{l}\text { Fire spots } \\
\text { intensity }\end{array}$ & Transport & $\begin{array}{l}\text { Sources of biomass } \\
\text { burning }\end{array}$ \\
\hline IAP & $2016 / 11 / 22$ & 10.9 & 0.14 & 96.1 & Low & from IM and HB & Low intensity \\
\hline IAP & $2016 / 11 / 24$ & 117.1 & 1.35 & 458.7 & Low & from IM and HB & Local \\
\hline IAP & $2016 / 11 / 26$ & 209.4 & 1.43 & 227.4 & High & from IM and HB & Regional \\
\hline IAP & 2016/12/1 & 49.4 & 0.82 & 192.3 & High & from IM and HB & Regional \\
\hline IAP & $2016 / 12 / 2$ & 98.6 & 1.51 & 515.4 & High & from IM and HB & Regional + local \\
\hline IAP & $2016 / 12 / 3$ & 239.9 & 1.94 & 634.8 & Low & from $\mathrm{HB}$ and $\mathrm{SX}$ & local \\
\hline IAP & $2016 / 12 / 4$ & 128.6 & 1.02 & 321.7 & Low & from IM and HB & local \\
\hline PG & $2016 / 11 / 22$ & 16.8 & 0.85 & 216.6 & Low & from IM and HB & Local \\
\hline PG & $2016 / 11 / 24$ & 106.8 & 2.52 & 915.6 & Low & from IM and HB & Local \\
\hline PG & $2016 / 11 / 26$ & 239.6 & 4.34 & 913.7 & High & from IM and HB & Regional + local \\
\hline PG & $2016 / 12 / 1$ & 41.0 & 1.22 & 311.2 & High & from IM and $\mathrm{HB}$ & Regional \\
\hline PG & $2016 / 12 / 2$ & 138.2 & 1.34 & 780.0 & High & from IM and HB & Regional + local \\
\hline PG & $2016 / 12 / 3$ & 281.5 & 2.62 & 1406.3 & Low & from $\mathrm{HB}$ and $\mathrm{SX}$ & Strong local \\
\hline PG & $2016 / 12 / 4$ & 294.3 & 2.70 & 1796.1 & Low & from IM and HB & Strong local \\
\hline IAP & $2017 / 5 / 24$ & 12.2 & 0.55 & 13.0 & High & from IM, LN, HB & Regional \\
\hline IAP & $2017 / 5 / 26$ & 34.7 & 0.44 & 22.1 & High & from IM, HB & Regional \\
\hline IAP & $2017 / 5 / 27$ & 78.8 & 0.49 & 20.1 & High & from IM, HB & Regional \\
\hline IAP & $2017 / 6 / 10$ & 18.6 & 0.46 & 11.6 & Low & from IM, LN, HB & Low intensity \\
\hline IAP & $2017 / 6 / 16$ & 44.3 & 0.40 & 51.9 & High & from $\mathrm{SD}, \mathrm{HB}$ & Regional + local \\
\hline IAP & $2017 / 6 / 17$ & 66.7 & 0.77 & 179.6 & High & from $\mathrm{SX}, \mathrm{HB}$ & Regional + local \\
\hline PG & $2017 / 5 / 26$ & 37.4 & 0.58 & 56.4 & High & from $\mathrm{SD}, \mathrm{HB}$ & Regional \\
\hline PG & $2017 / 5 / 27$ & 70.3 & 0.85 & 89.8 & High & from IM, HB & Regional + local \\
\hline PG & $2017 / 6 / 10$ & 11.6 & 0.65 & 56.9 & Low & from $\mathrm{HB}, \mathrm{TJ}$ & Local \\
\hline PG & $2017 / 6 / 16$ & 47.4 & 0.72 & 107.1 & Very high & from $\mathrm{HB}$ & Regional + local \\
\hline PG & $2017 / 6 / 17$ & 46.7 & 0.96 & 219.8 & Very high & from IM, SX, HB & Regional + local \\
\hline
\end{tabular}


Table S3. Summary of EC/OC and OC/LG ratios of different biomass types and the ranges of fractions in LG.

\begin{tabular}{|c|c|c|c|c|}
\hline No. & Sample & $\mathrm{EC} / \mathrm{OC}$ & $\mathrm{OC} / \mathrm{LG}$ & Reference \\
\hline 1 & Slash pine & 0.141 & 0.341 & Fine et al., 2002 \\
\hline 2 & Ponderosa pine & 0.014 & 7.83 & Fine et al., 2001 \\
\hline 3 & Western hemlock & 0.050 & 2.52 & Hays et al., 2002 \\
\hline 4 & Loblolly pine & 0.178 & 1.02 & Fine et al., 2002 \\
\hline 5 & Douglas fir & 0.098 & 2.45 & Fine et al., 2004 \\
\hline 6 & Eastern hemlock & 0.053 & 10.5 & Fine et al., 2001 \\
\hline 7 & White pine needle & 0.078 & 7.18 & Mazzoleni et al., 2007 \\
\hline 8 & Larch & 0.176 & 3.68 & Schmidl et al., 2008b \\
\hline 9 & Balsam fir & 0.066 & 12.3 & Fine et al., 2001 \\
\hline 10 & Douglas fir (catalyst) & 0.338 & 2.52 & Fine et al., 2004 \\
\hline 11 & Loblolly pine & 0.307 & 3.95 & Fine et al., 2004 \\
\hline 12 & Chestnut oak & 0.312 & 3.94 & Wang et al., 2009 \\
\hline 13 & White pine needle & 0.282 & 4.71 & Mazzoleni et al., 2007 \\
\hline 14 & White pine needle & 0.242 & 6.61 & Mazzoleni et al., 2007 \\
\hline 15 & Spruce & 0.384 & 5.02 & Schmidl et al., 2008b \\
\hline 16 & Mixed wood & 0.288 & 6.76 & Mazzoleni et al., 2007 \\
\hline 17 & White pine needle & 0.331 & 6.64 & Mazzoleni et al., 2007 \\
\hline 18 & Chinese evergreen Chinkapin & 0.078 & 33.8 & Wang et al., 2009 \\
\hline 19 & Chinese red pine & 0.375 & 8.33 & Sang-Arlt et al., 2020 \\
\hline 20 & Cape jasmine & 0.137 & 27.9 & Wang et al., 2009 \\
\hline 21 & Ponderosa pine needles & 0.401 & 10.2 & Mazzoleni et al., 2007 \\
\hline 22 & Common aporusa & 0.095 & 43.3 & Wang et al., 2009 \\
\hline 23 & Samak & 0.054 & 137 & Wang et al., 2009 \\
\hline 24 & Cedar wood & 0.090 & 96.9 & Mazzoleni et al., 2007 \\
\hline 25 & Excelsior & 1.080 & 5.87 & Mazzoleni et al., 2007 \\
\hline 26 & Excelsior & 1.090 & 6.13 & Mazzoleni et al., 2007 \\
\hline 27 & Eastern white pine & 0.426 & 19.1 & Fine et al., 2001 \\
\hline 28 & Maritime pine & 1.420 & 6.87 & Goncalves et al., 2010 \\
\hline
\end{tabular}




\begin{tabular}{lllll}
29 & China fir & 0.651 & 16.7 & Sang-Arlt et al., 2020 \\
30 & Ponderosa pine needles & 1.320 & 15.4 & Mazzoleni et al., 2007 \\
31 & Cedar wood & 0.264 & 94.4 & Mazzoleni et al., 2007 \\
32 & Ponderosa pine needles & 1.500 & 17.4 & Mazzoleni et al., 2007 \\
33 & Wood & 0.500 & 55.6 & Schmidl et al., 2008a \\
34 & Ponderosa pine needles & 0.632 & 55.4 & Mazzoleni et al., 2007 \\
35 & Tamarak pine wood & 0.330 & 137 & Mazzoleni et al., 2007 \\
36 & Ponderosa pine sticks & 3.320 & 20.1 & Mazzoleni et al., 2007 \\
37 & Ponderosa pine sticks & 3.680 & 25.6 & Mazzoleni et al., 2007 \\
38 & Wood branch charcoal & 0.393 & 625 & Sun et al., 2019 \\
39 & Spruce with green needles & 0.401 & 2128 & Schmidl et al., 2008b \\
40 & Pine & 0.508 & 2128 & Schauer et al., 2001 \\
41 & Pine with green needles & 0.600 & 3571 & Schauer et al., 2001 \\
\hline No. & Sample & EC/OC & OC/LG & Reference \\
\hline 42 & Wheat straw & 0.223 & 4.07 & Sun et al., 2019 \\
43 & Wheat straw & 0.068 & 15.4 & Fushimi et al., 2017 \\
44 & Wheat straw & 0.083 & 15.2 & Fushimi et al., 2017 \\
45 & Wheat straw & 0.184 & 12.5 & Dhammapala et al., 2007 \\
46 & Wheat straw & 0.422 & 10 & Hays et al., 2005 \\
47 & Wheat straw & 0.510 & 9.09 & Mazzoleni et al., 2007 \\
48 & Maize straw & 0.257 & 3.18 & Sun et al., 2019 \\
49 & Maize straw & 0.106 & 55.6 & Yan et al., 2018 \\
50 & Cereal straw & 0.130 & 12 & Zhang et al., 2007 \\
\hline
\end{tabular}


Table S4. The estimated $\mathrm{OC} / \mathrm{EC}_{\mathrm{nf}}$, min and $\mathrm{OC}_{\mathrm{EC}}$, min ratios for IAP and PG sites during the whole winter and summer sampling period

\begin{tabular}{|c|c|c|c|c|c|}
\hline & $\begin{array}{l}\text { lowest } 5 \\
\% \\
\text { OC/EC }\end{array}$ & $\begin{array}{l}\text { lowest } 2 \\
\frac{f_{\mathrm{NF}, \mathrm{OC}}}{\mathrm{f}_{\mathrm{NF}, \mathrm{EC}}}\end{array}$ & $\begin{array}{l}\text { lowest } 2 \\
\left(\frac{1-\mathrm{f}_{\mathrm{NF}, \mathrm{OC}}}{1-\mathrm{f}_{\mathrm{NF}, \mathrm{EC}}}\right)\end{array}$ & $\begin{array}{l}\text { Estimated } \\
\mathrm{OC} / \mathrm{EC}_{\mathrm{nf}, \text { min }}\end{array}$ & 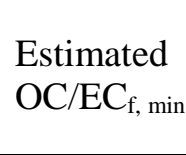 \\
\hline IAP winter & 4.35 & 0.70 & 0.96 & 3.06 & 4.16 \\
\hline PG winter & 6.27 & 0.76 & 0.81 & 4.76 & 5.09 \\
\hline IAP summer & 4.65 & 0.73 & 0.78 & 3.41 & 3.62 \\
\hline PG summer & 4.45 & 0.88 & 0.62 & 3.92 & 2.76 \\
\hline
\end{tabular}

$\mathrm{f}_{\mathrm{NF}}, \mathrm{OC}$ and $\mathrm{f}_{\mathrm{NF}} \mathrm{EC}$ are the non-fossil fractions of OC and EC, $\left(1-\mathrm{f}_{\mathrm{NF}}, \mathrm{OC}\right)$ and $\left(1-\mathrm{f}_{\mathrm{NF}} \mathrm{EC}\right)$ are the fossil fractions of OC and EC. 
Table S5. Summary of Cholesterol and element concentrations, EFs, $\mathrm{OC}_{\mathrm{ck}-\mathrm{ch}}, \mathrm{OC}_{\mathrm{onf}}, \mathrm{OC}_{\mathrm{dt}}$ and $\mathrm{OC}_{\mathrm{dt}-\mathrm{Al}}$.

\begin{tabular}{|c|c|c|c|c|c|c|c|c|c|c|c|c|c|}
\hline Site & Date & $\begin{array}{l}\text { Cholesterol } \\
\mathrm{ng} \mathrm{m}^{-3}\end{array}$ & $\begin{array}{l}\mathrm{Si} \\
\mathrm{ng} \mathrm{m}^{-3}\end{array}$ & $\begin{array}{l}\mathrm{Al} \\
\mathrm{ng} \mathrm{\textrm {m } ^ { - 3 }}\end{array}$ & $\begin{array}{l}\mathrm{Fe} \\
\mathrm{ng} \mathrm{m}^{-3}\end{array}$ & $\begin{array}{l}\mathrm{Ti} \\
\mathrm{ng} \mathrm{m}^{-3}\end{array}$ & $\begin{array}{l}\mathrm{OC}_{\mathrm{ck}-\mathrm{ch}} \\
\mu \mathrm{g} \mathrm{m}^{-3}\end{array}$ & $\begin{array}{l}\mathrm{OC}_{\mathrm{onf}} \\
\mu \mathrm{g} \mathrm{m}^{-3}\end{array}$ & $\mathrm{EF}(\mathrm{Si})$ & $\mathrm{EF}(\mathrm{Fe})$ & $\mathrm{EF}(\mathrm{Ti})$ & $\begin{array}{l}\mathrm{OC}_{\mathrm{dt}} \\
\mu \mathrm{g} \mathrm{m}^{-3}\end{array}$ & $\begin{array}{l}\mathrm{OC}_{\mathrm{dt}-\mathrm{Al}} \\
\mu \mathrm{g} \mathrm{m}^{-3}\end{array}$ \\
\hline IAP & $22 / 11 / 2016$ & 1.10 & 141.6 & 68.8 & 190.4 & 34.6 & 2.16 & -2.23 & 0.71 & 2.64 & 6.38 & $0.02-0.14$ & $0.03-0.15$ \\
\hline IAP & $24 / 11 / 2016$ & 1.39 & 335.2 & 229.5 & 526.9 & 8.8 & 2.71 & -1.80 & 0.50 & 2.19 & 0.49 & $0.05-0.32$ & $0.10-0.50$ \\
\hline IAP & $26 / 11 / 2016$ & 1.08 & 2819.5 & 1372.1 & 1053.1 & 68.8 & 2.11 & -0.11 & 0.71 & 0.73 & 0.64 & $0.41-2.70$ & $0.58-3.01$ \\
\hline IAP & $01 / 12 / 2016$ & 1.61 & 459.7 & 313.7 & 350.7 & 0.0 & 3.15 & -2.22 & 0.51 & 1.06 & 0.00 & $0.07-0.44$ & $0.13-0.69$ \\
\hline IAP & $02 / 12 / 2016$ & 0.18 & 778.7 & 569.8 & 435.8 & 3.1 & 0.36 & 0.62 & 0.47 & 0.73 & 0.07 & $0.11-0.75$ & $0.24-1.25$ \\
\hline IAP & $03 / 12 / 2016$ & 0.37 & 1551.3 & 1319.9 & 1032.8 & 25.6 & 0.72 & 1.17 & 0.41 & 0.75 & 0.25 & $0.22-1.49$ & $0.55-2.90$ \\
\hline IAP & $04 / 12 / 2016$ & 1.73 & 2244.7 & 1635.2 & 467.0 & 18.3 & 3.38 & -2.34 & 0.47 & 0.27 & 0.14 & $0.33-2.15$ & $0.69-3.59$ \\
\hline IAP & $24 / 05 / 2017$ & 0.46 & 43.4 & 25.0 & 283.9 & 5.7 & 0.90 & 0.77 & 0.60 & 10.82 & 2.89 & 0.01-0.04 & $0.01-0.05$ \\
\hline IAP & $26 / 05 / 2017$ & 1.14 & 645.2 & 297.3 & 621.8 & 27.6 & 2.22 & -1.05 & 0.75 & 1.99 & 1.18 & $0.09-0.62$ & $0.12-0.65$ \\
\hline IAP & $27 / 05 / 2017$ & 1.65 & 741.6 & 346.6 & 1149.8 & 32.1 & 3.22 & -1.83 & 0.74 & 3.16 & 1.17 & $0.11-0.71$ & $0.15-0.76$ \\
\hline IAP & $10 / 06 / 2017$ & 0.38 & 1102.6 & 466.2 & 579.6 & 32.7 & 0.73 & 0.64 & 0.82 & 1.18 & 0.89 & $0.16-1.06$ & $0.20-1.02$ \\
\hline IAP & $16 / 06 / 2017$ & 0.40 & 793.0 & 302.9 & 433.0 & 37.3 & 0.78 & -0.05 & 0.90 & 1.36 & 1.56 & $0.11-0.76$ & $0.13-0.67$ \\
\hline IAP & $17 / 06 / 2017$ & 1.00 & 584.0 & 188.2 & 488.7 & 19.9 & 1.96 & -1.44 & 1.07 & 2.47 & 1.34 & $0.08-0.56$ & 0.08-0.41 \\
\hline PG & $22 / 11 / 2016$ & 0.70 & n.a & 55.8 & 220.2 & 18.9 & 1.36 & 1.14 & n.a & 3.76 & 4.30 & n.a & $0.02-0.12$ \\
\hline PG & 24/11/2016 & 1.25 & n.a & 395.8 & 1354.9 & 51.9 & 2.44 & 4.31 & n.a & 3.26 & 1.66 & n.a & $0.17-0.87$ \\
\hline PG & $26 / 11 / 2016$ & 1.75 & n.a & 1153.9 & 1979.3 & 164.7 & 3.42 & 9.65 & n.a & 1.63 & 1.81 & n.a & $0.48-2.53$ \\
\hline PG & $01 / 12 / 2016$ & 1.08 & n.a & 111.2 & 244.5 & 2.6 & 2.11 & 1.45 & n.a & 2.09 & 0.30 & n.a & $0.05-0.24$ \\
\hline PG & $02 / 12 / 2016$ & 0.94 & n.a & 452.6 & 625.0 & 5.6 & 1.84 & 1.03 & n.a & 1.32 & 0.16 & n.a & $0.19-0.99$ \\
\hline PG & 03/12/2016 & 1.46 & n.a & 897.2 & 1206.4 & 32.5 & 2.85 & 3.17 & n.a & 1.28 & 0.46 & n.a & $0.38-1.97$ \\
\hline PG & $04 / 12 / 2016$ & 2.30 & n.a & 322.1 & 381.3 & 7.0 & 4.50 & 1.14 & n.a & 1.13 & 0.28 & n.a & 0.14-0.71 \\
\hline PG & $26 / 05 / 2017$ & 0.31 & 480.0 & 273.3 & 9.5 & 29.4 & 0.60 & 0.47 & 0.61 & 0.03 & 1.36 & $0.07-0.46$ & $0.11-0.60$ \\
\hline PG & 27/05/2017 & 0.17 & 736.9 & 338.0 & 17.5 & 29.2 & 0.34 & 1.87 & 0.75 & 0.05 & 1.10 & $0.11-0.71$ & $0.14-0.74$ \\
\hline PG & $10 / 06 / 2017$ & 0.65 & 614.9 & 257.1 & 4.9 & 24.7 & 1.26 & 0.31 & 0.82 & 0.02 & 1.22 & $0.09-0.59$ & $0.11-0.56$ \\
\hline PG & $16 / 06 / 2017$ & 0.68 & 786.8 & 325.3 & 9.2 & 27.2 & 1.32 & 5.92 & 0.83 & 0.03 & 1.06 & $0.11-0.75$ & $0.14-0.71$ \\
\hline PG & $17 / 06 / 2017$ & 0.55 & 674.3 & 217.7 & 10.9 & 23.3 & 1.07 & 0.57 & 1.07 & 0.05 & 1.36 & $0.10-0.65$ & $0.09-0.48$ \\
\hline
\end{tabular}


1 Table S6. Correlations and slopes among WINSOC, WSOC, POC, SOC, OC $\mathrm{bb}$ and $\mathrm{OC}_{\mathrm{ck}}$ at IAP 2 and $\mathrm{PG}$ in winter and summer.

\begin{tabular}{llllllllll}
\hline \multirow{2}{*}{$\mathrm{x}$} & & \multicolumn{2}{c}{ IAP winter } & \multicolumn{2}{c}{ PG winter } & \multicolumn{2}{c}{ IAP summer } & \multicolumn{2}{c}{ PG summer } \\
& & slope & $\mathrm{R}^{2}$ & slope & $\mathrm{R}^{2}$ & slope & $\mathrm{R}^{2}$ & slope & $\mathrm{R}^{2}$ \\
\hline \multirow{2}{*}{ POC $_{\mathrm{f}}$} & WINSOC $_{\mathrm{f}}$ & 1.11 & 0.97 & 1.23 & 0.97 & 0.92 & 0.93 & 0.84 & 0.82 \\
& WSOC $_{\mathrm{f}}$ & 0.57 & 0.99 & 0.61 & 0.84 & 0.96 & 0.92 & 0.58 & 0.55 \\
\multirow{2}{*}{ SOC $_{\mathrm{f}}$} & WINSOC $_{\mathrm{f}}$ & 1.53 & 0.96 & 1.27 & 0.89 & 0.99 & 0.91 & 0.98 & 0.45 \\
& WSOC $_{\mathrm{f}}$ & 0.78 & 0.93 & 0.69 & 0.96 & 1.05 & 0.93 & 0.89 & 0.67 \\
$\mathrm{OCC}_{\mathrm{bb}}$ & WINSOC $_{\mathrm{nf}}$ & 1.59 & 1.00 & 2.38 & 0.94 & 1.16 & 0.44 & 1.58 & 0.91 \\
& WSOC $_{\mathrm{nf}}$ & 1.64 & 0.94 & 1.70 & 0.92 & 3.41 & 0.93 & 1.54 & 0.93 \\
OC $_{\mathrm{ck}}$ & WINSOC $_{\mathrm{nf}}$ & 3.54 & 0.88 & 1.68 & 0.69 & 1.08 & 0.74 & 2.26 & 0.27 \\
& WSOC $_{\mathrm{nf}}$ & 3.83 & 0.94 & 1.21 & 0.69 & 1.53 & 0.19 & 2.29 & 0.32 \\
SOC $_{\mathrm{nf}}$ & WINSOC $_{\mathrm{nf}}$ & 0.85 & 0.98 & 0.98 & 0.83 & 0.42 & 0.65 & 0.79 & 0.92 \\
& WSOC $_{\mathrm{nf}}$ & 0.90 & 0.99 & 0.71 & 0.83 & 1.09 & 0.97 & 0.75 & 0.88 \\
\hline
\end{tabular}

3 f: fossil sources, nf: non-fossil sources, bb: biomass burning, ck: cooking. Concentrations of fossil 4 and non-fossil sources of WINSOC and WSOC were from ${ }^{14} \mathrm{C}$ measurement. POC, SOC, OCbb and $5 \quad \mathrm{OC}_{\mathrm{ck}}$ are from extended Gelencsér method. 


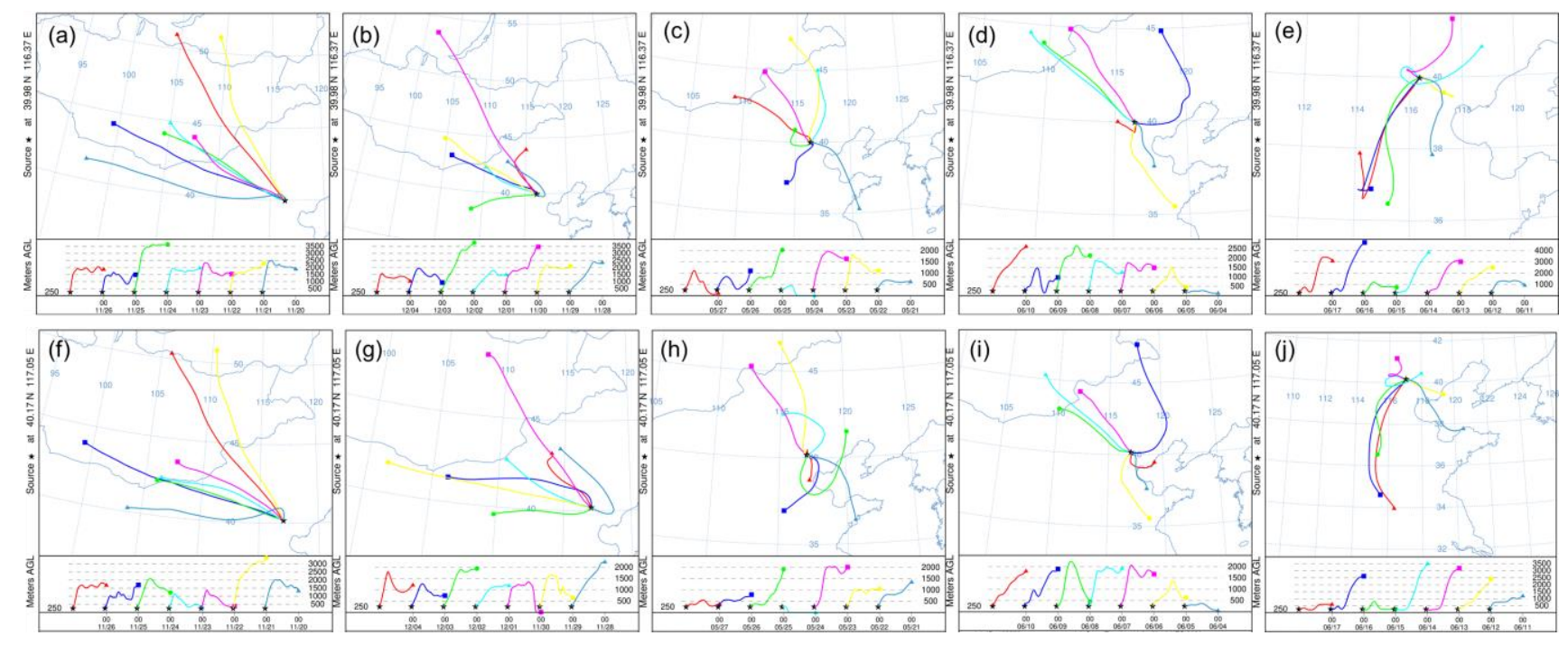

8 Figure S1. $48 \mathrm{~h}$ air-mass back trajectories with $24 \mathrm{~h}$ interval at $250 \mathrm{~m}$, (a)-(e): destination at IAP, 9 (f)-(j): destination at PG. (https://ready.arl.noaa.gov/HYSPLIT.php, last access: 12 June 2020) 10 

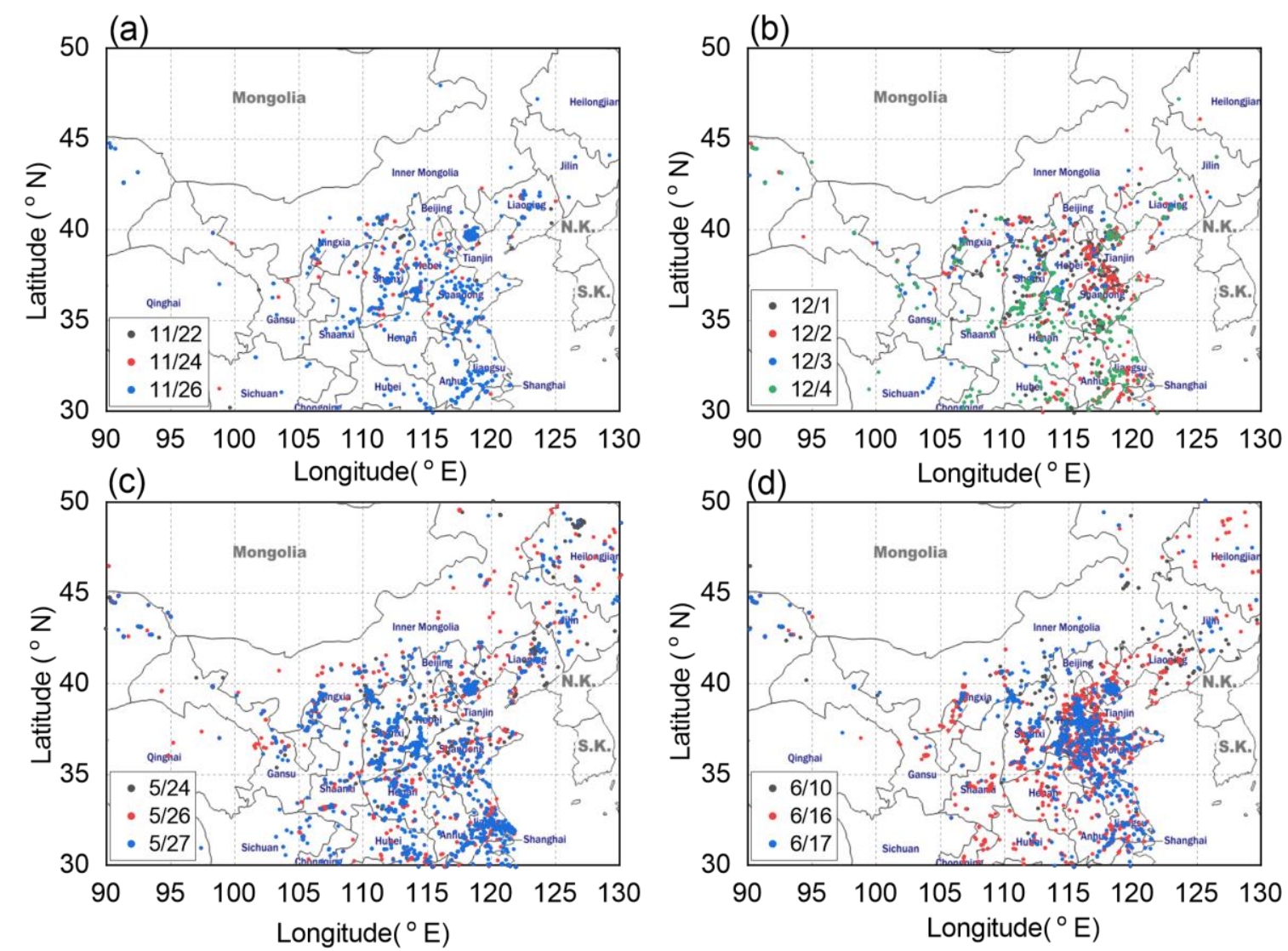

12 Figure S2. Fire spots observed by MODIS (AQUA/TERRA)

13 (https://firms.modaps.eosdis.nasa.gov/alerts/, last access: 16 April 2020) around Beijing, coloured

14 dots refer to fire spots on (a): 22, 24, 26 Nov 2016, (b): 1-4 Dec 2016, (c): 24, 26, 27 May 2017, (d)

$1510,16,17$ Jun 2017. 

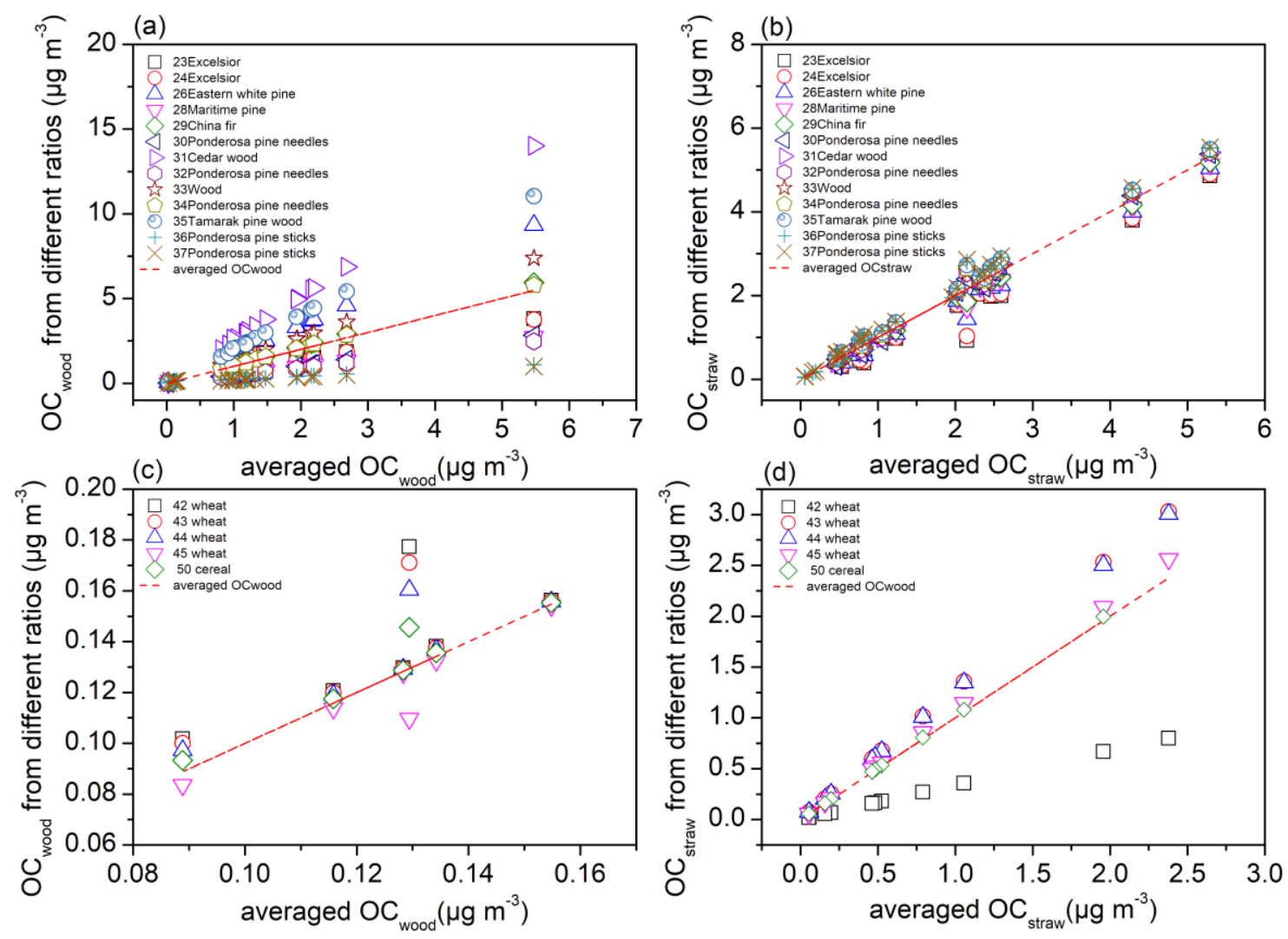

Figure S3. Correlations of averaged $\mathrm{OC}_{\text {wood }}$ with $\mathrm{OC}_{\text {wood }}$ from different ratios and averaged $\mathrm{OC}_{\text {straw }}$

19 with $\mathrm{OC}_{\text {straw }}$ from different ratios. (a), the influence of ratios from softwood on the estimation of

$20 \mathrm{OC}_{\mathrm{wood}}$; (b), the influence of ratios from softwood on the estimation of $\mathrm{OC}_{\text {straw }}$; (c), the influence of

21 ratios from wheat straws on the estimation of $\mathrm{OC}_{\mathrm{wood}}$; (d), the influence of ratios from wheat straws

22 on the estimation of $\mathrm{OC}_{\text {straw. }}$. As there is only one set of ratios from maize straw which matches the

23 selection limitation, the influence of ratios from maize straw was not plotted. The legends correspond

24 to the No. and types of samples in Table S3. 

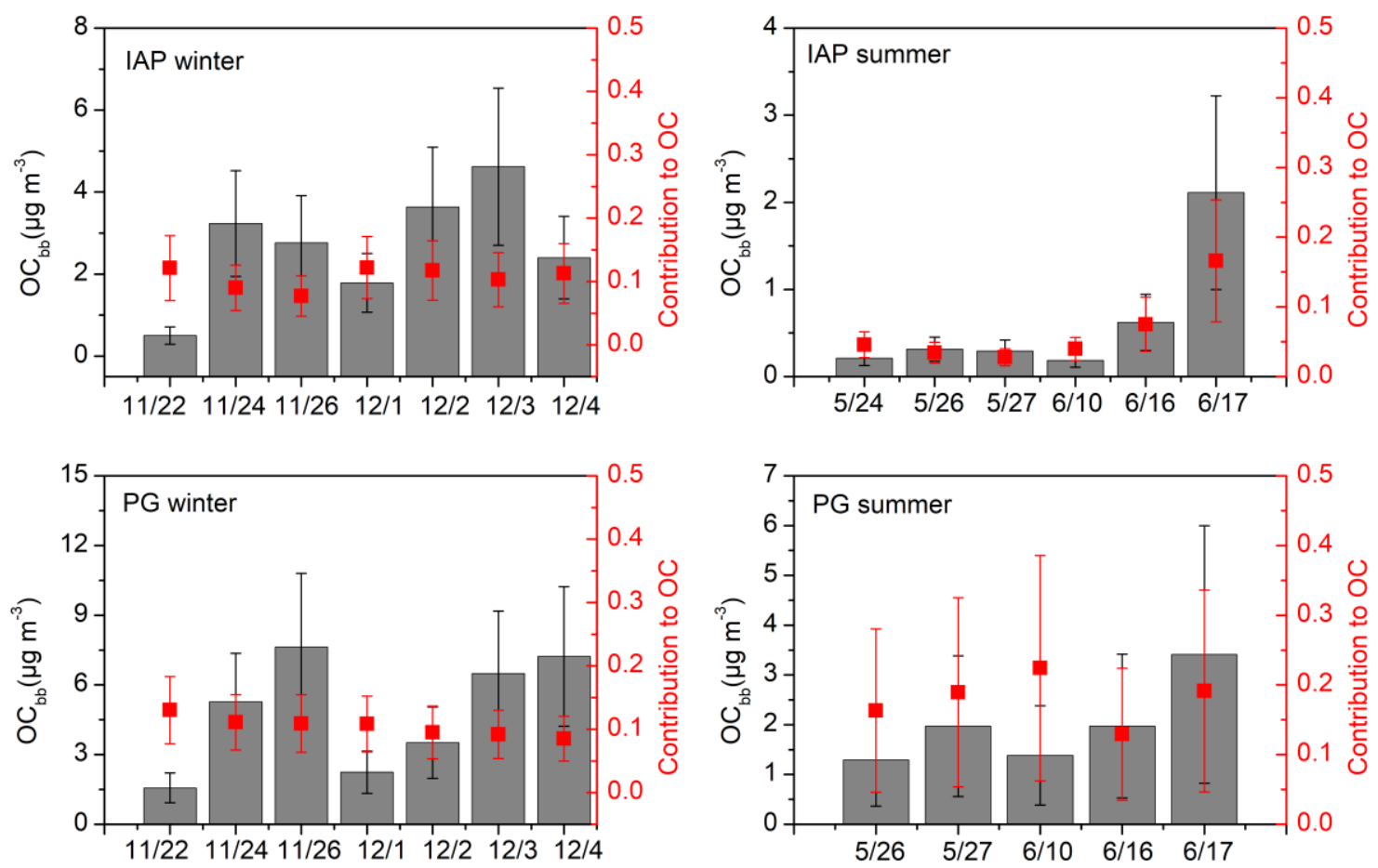

27 Figure S4. The mass concentrations and $\%$ contributions of $\mathrm{OC}_{\mathrm{bb}}$ at IAP and PG during winter and 28 summer. 

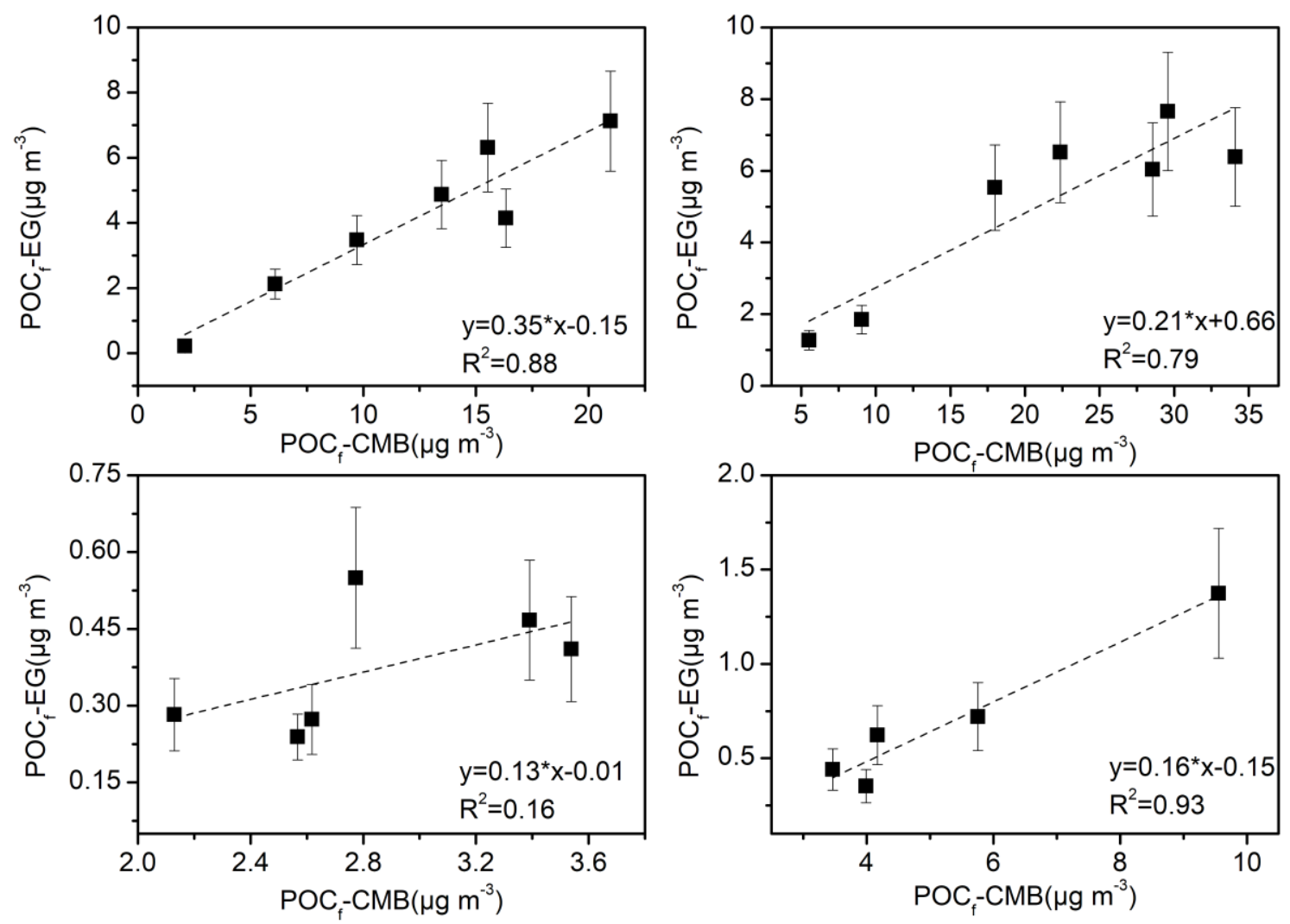

Figure S5. Correlations of $\mathrm{POC}_{\mathrm{f}}$ from the extended Gelencsér method $\left(\mathrm{POC}_{\mathrm{f}}-\mathrm{EG}\right)$ and $\mathrm{CMB}$ if 32 using $(\mathrm{POC} / \mathrm{EC})_{\mathrm{f}}$ ratios $1.12-2.08$ in winter, $0.40-0.77$ in summer. 

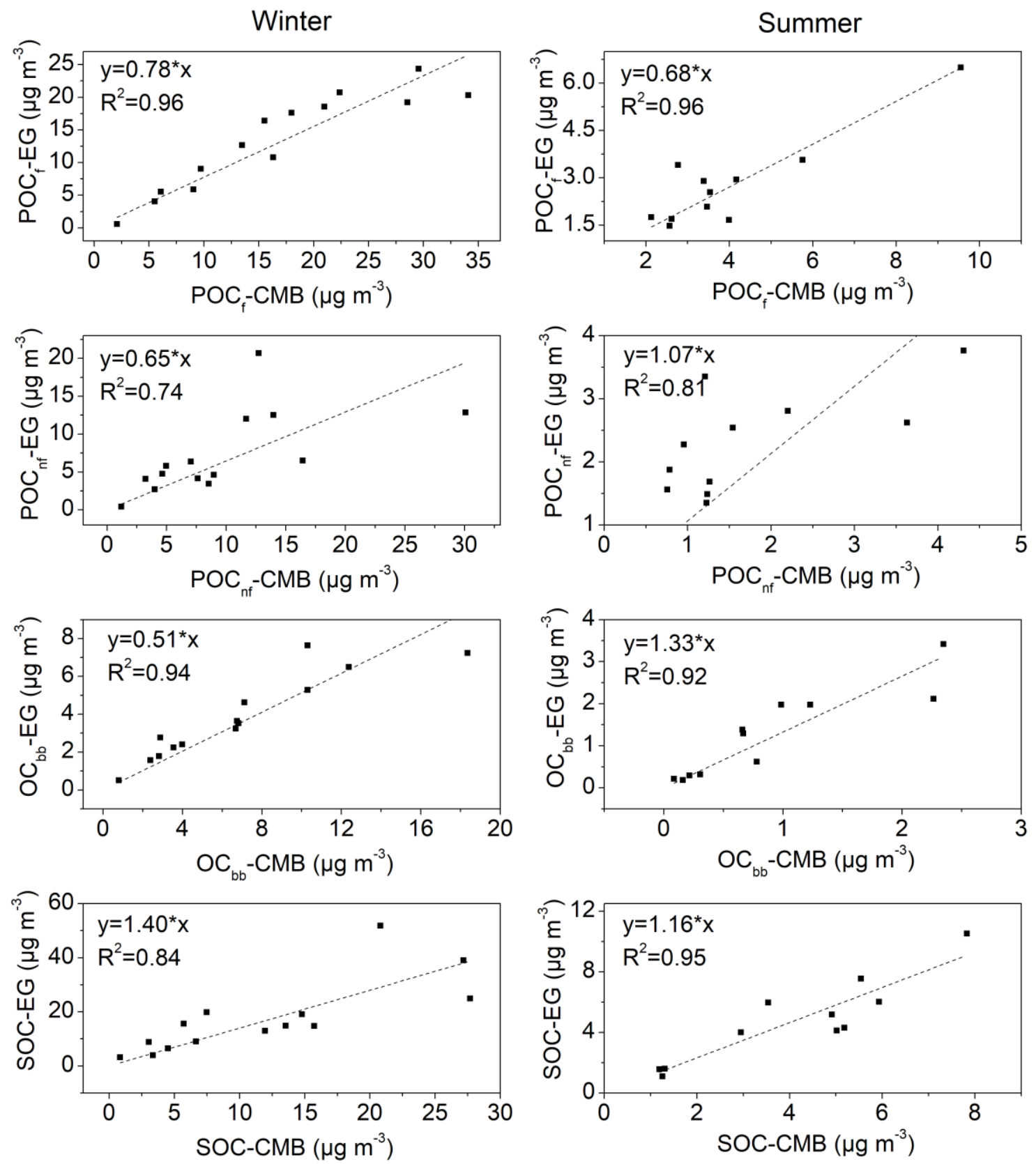

35 Figure S6. Correlations of OC sources from extended Gelencsér method with those from CMB 36 model in winter (left) and summer (right). EG denotes extended Gelencsér method. 

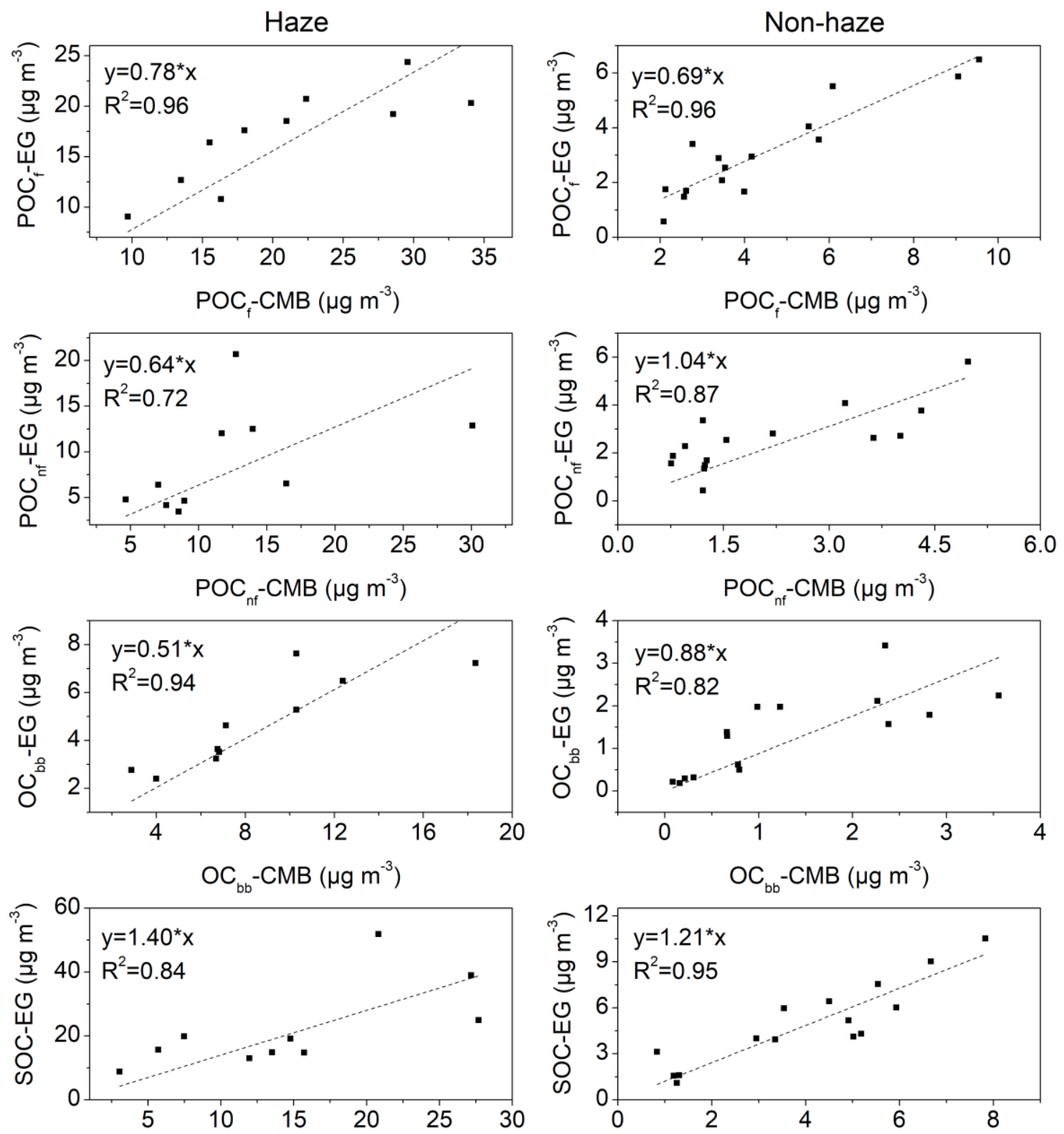

$$
\text { SOC-CMB }\left(\mu \mathrm{g} \mathrm{m}^{-3}\right)
$$

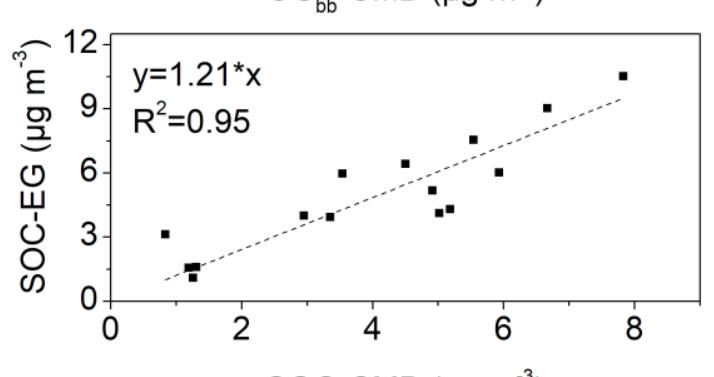

39 Figure S7. Correlations of OC sources from extended Gelencsér method with those from CMB 40 model during haze period (left) and non-haze period (right). EG denotes extended Gelencsér method. 

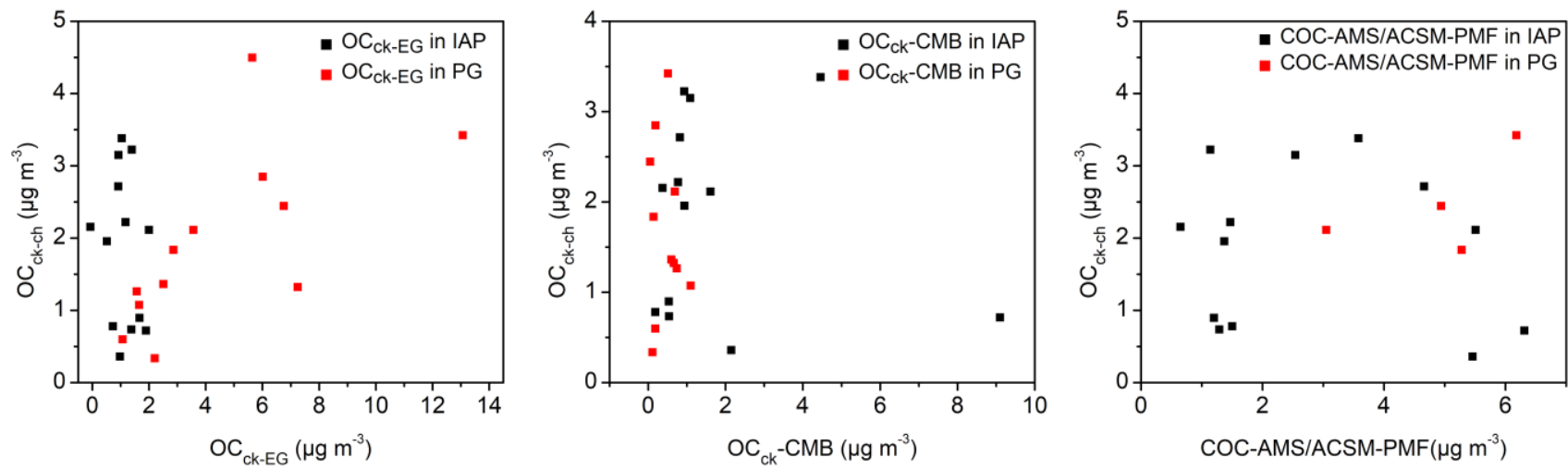

45 Figure S8. Correlations of $\mathrm{OC}_{\mathrm{ck}-\mathrm{ch}}$ with $\mathrm{OC}_{\mathrm{ck}-\mathrm{EG}}, \mathrm{OC}_{\mathrm{ck}}-\mathrm{CMB}$ and COC-AMS/ACSM-PMF. OC $\mathrm{C}_{\mathrm{ck}-\mathrm{ch}}$, 46 OC from cooking from cholesterol concentrations and cholesterol to $\mathrm{OC}$ ratios; $\mathrm{OC}_{\mathrm{ck}-\mathrm{EG}}$, OC from

47 cooking from extended Gelencsér method; $\mathrm{OC}_{\mathrm{ck}} \mathrm{CMB}, \mathrm{OC}$ from cooking from $\mathrm{CMB}$ model; COC-

48 AMS/ACSM-PMF, OC from cooking from AMS/ACSM-PMF model (AMS for IAP and ACSM for 49 PG).

50 

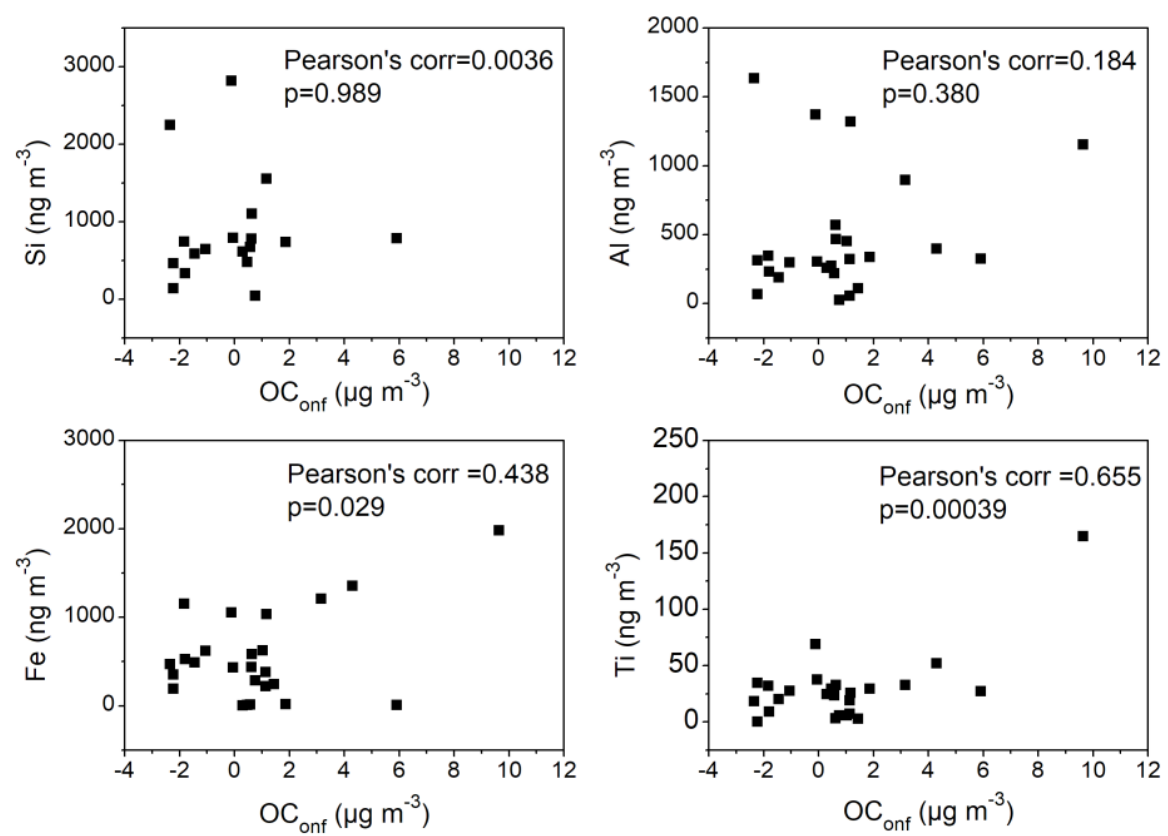

53 Figure S9. Correlations of $\mathrm{OC}_{\text {onf }}\left(=\mathrm{OC}_{\mathrm{ck}-\mathrm{EG}-\mathrm{OC}} \mathrm{ck-ch}\right)$ with $\mathrm{Si}$ (no data in winter campaign of $\left.\mathrm{PG}\right)$, $54 \mathrm{Al}, \mathrm{Fe}$ and Ti. $\mathrm{OC}_{\mathrm{ck}-\mathrm{ch}}, \mathrm{OC}$ from cooking from cholesterol concentrations and cholesterol to OC 55 ratios; $\mathrm{OC}_{\mathrm{ck}-\mathrm{EG}}$, $\mathrm{OC}$ from cooking from extended Gelencsér method. 